\title{
Chronic treatment with anesthetic propofol attenuates $\beta$-amyloid protein levels in brain tissues of aged mice
}

\author{
Yiying Zhang ${ }^{1 \dagger}$, Haijun Shao ${ }^{1,2+}$, Yuanlin Dong ${ }^{1}$, Celeste A Swain ${ }^{1}$, Buwei Yu ${ }^{2}$, Weiming Xia ${ }^{3}$ and Zhongcong Xie ${ }^{1 *}$
}

\begin{abstract}
Alzheimer's disease (AD) is the most common form of dementia. At the present time, however, AD still lacks effective treatments. Our recent studies showed that chronic treatment with anesthetic propofol attenuated brain caspase-3 activation and improved cognitive function in aged mice. Accumulation of $\beta$-amyloid protein $(A \beta)$ is a major component of the neuropathogenesis of AD dementia and cognitive impairment. We therefore set out to determine the effects of chronic treatment with propofol on A levels in brain tissues of aged mice. Propofol $(50 \mathrm{mg} / \mathrm{kg})$ was administrated to aged (18 month-old) wild-type mice once a week for 8 weeks. The brain tissues of mice were harvested one day after the final propofol treatment. The harvested brain tissues were then subjected to enzyme-linked immunosorbent assay (ELISA) and Western blot analysis. Here we report that the propofol treatment reduced $A \beta$ ( $A \beta 40$ and $A \beta 42$ ) levels in the brain tissues of the aged mice. Moreover, the propofol treatment decreased the levels of $\beta$-site amyloid precursor protein cleaving enzyme (the enzyme for $A \beta$ generation), and increased the levels of neprilysin (the enzyme for $A \beta$ degradation) in the brain tissues of the aged mice. These results suggested that the chronic treatment with propofol might reduce brain $A \beta$ levels potentially via decreasing brain levels of $\beta$-site amyloid precursor protein cleaving enzyme, thus decreasing $A \beta$ generation; and via increasing brain neprilysin levels, thus increasing $A \beta$ degradation. These preliminary findings from our pilot studies have established a system and postulated a new hypothesis for future research.
\end{abstract}

Keywords: Aging, Alzheimer's disease, Neurodegeneration, $\beta$-amyloid peptide, Anesthesia, Propofol

\section{Introduction}

Alzheimer disease (AD) is an insidious and progressive neurodegenerative disorder accounting for the vast majority of dementia, and is characterized by global cognitive decline and the robust accumulation of amyloid deposits and neurofibrillary tangles in the brain (reviewed in [1]). However, there is still a lack of effective treatments for $\mathrm{AD}$, and many studies aim to find new and novel drugs to treat and/or prevent $\mathrm{AD}$.

$\beta$-Amyloid protein $(A \beta)$ is a main component of the plaques found in brains of $\mathrm{AD}$ patients and is the hallmark of $\mathrm{AD}$ dementia and cognitive impairment (reviewed in [1]). Accumulation and deposition of $\beta$-amyloid protein $(\mathrm{A} \beta)$ has been reported as one of the main aspects of $\mathrm{AD}$

\footnotetext{
* Correspondence: zxie@mgh.harvard.edu

${ }^{\dagger}$ Equal contributors

${ }^{1}$ Geriatric Anesthesia Research Unit, Department of Anesthesia, Critical Care and Pain Medicine, Massachusetts General Hospital and Harvard Medical School, 149 13th St., Room 4310, Charlestown, MA 02129-2060, USA Full list of author information is available at the end of the article
}

neuropathogenesis ([2-4], reviewed in [1]). A $\beta$ was isolated from meningovascular amyloid deposits in $\mathrm{AD}$ and Down's syndrome $[2,5]$. These findings led to the cloning of the gene encoding amyloid precursor protein (APP) as one of the $\mathrm{AD}$ genes $[6,7]$ and consequently, the further studies of APP processing and A $\beta$ metabolism.

APP is hydrolyzed by aspartyl protease $\beta$-site APPcleaving enzyme (BACE) or $\beta$-secretase, a type I transmembrane, glycosylated aspartyl protease found in post-Golgi membranes and at the cell surface [8-11], and then is cleaved by $\gamma$-secretase [12-14] to generate $A \beta$. Finally, $A \beta$ can be degraded by enzyme insulin degrading enzyme (IDE) and neprilysin (NEP) ([15-19]; reviewed in [20]).

Propofol (2, 6-disopropylphenol) is an intravenous anesthetic. It has been shown that propofol can attenuate the caspase- 3 activation and $A \beta$ oligomerization induced by the anesthetic isoflurane [21]. Our recent studies have shown that chronic treatment with propofol $(50 \mathrm{mg} / \mathrm{kg}$, once per

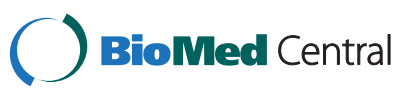


week for 8 weeks) in aged mice (e.g., 18 month-old) can improve the cognitive function and attenuate the caspase3 activation [22]. Given $A \beta$ accumulation can lead to cognitive impairment [reviewed in [1]), we set out in the present pilot studies to establish a system and to test a hypothesis that the chronic treatment with propofol can decrease $A \beta$ levels in the brain tissues of aged mice via inhibiting its generation and/or promoting its degradation. The findings from these proof of concept studies would promote more research to further determine the effects of anesthetic propofol on AD neuropathogenesis.

\section{Materials and methods}

\section{Mice and propofol treatment}

The animal protocol was approved by the Standing Committee on Animals at Massachusetts General Hospital, Boston, Massachusetts. The maintenance and handling of mice were consistent with the guideline of National Institute of Health, and all of the efforts were made to minimize the number of animals in the studies. Wild-type mice (C57BL/6 J, The Jackson Lab, Bar Harbor, ME) were used in the study. There were 10 mice in the propofol treatment group and 10 mice in the saline control group. The mice, at the age of 18 months-old, were randomized by weight and gender into experimental groups, which received propofol (APP Pharmaceuticals, Inc, Schaumburg, IL) treatment [50 mg/kg, intraperitoneal (IP) injection], and control groups, which received the same volume of saline (IP), once a week every Saturday for 8 weeks.

\section{Tissue preparation}

One day after the last propofol or saline treatment, mice were decapitated, and the brain tissues were harvested. The harvested brain tissues were homogenized on ice with an immunoprecipitation buffer $(10 \mathrm{mM}$ Tris- $\mathrm{HCl}, \mathrm{pH} 7.4$, $150 \mathrm{mM} \mathrm{NaCl}, 2 \mathrm{mM}$ ethylenediaminetetraacetic acid, $0.5 \%$ Nonidet P-40) plus protease inhibitors $(1 \mu \mathrm{g} / \mathrm{ml}$ aprotinin, $1 \mu \mathrm{g} / \mathrm{ml}$ leupeptin, $1 \mu \mathrm{g} / \mathrm{ml}$ pepstatin A). The lysates were centrifuged at 14,000 rpm for 15 minutes, and quantified for total protein concentration by a bicinchoninic acid protein assay kit (Pierce, Iselin, NJ). The harvested brain tissues were subjected to Enzymelinked immunosorbent assay (ELISA) or Western blot analyses as described in our previous studies [21,23,24].

\section{ELISA determination of $A$}

The mouse $A \beta 40$ (KMB3481) and A $\beta 42$ (KMB3441) immunoassay Kits (Invitrogen, San Francisco, CA) were used to determine the $A \beta 40$ and $A \beta 42$ levels in the brain tissues of the aged mice, respectively. The brain tissues were homogenized in TBS buffer (including $50 \mathrm{mM}$ Tris, and $150 \mathrm{mM} \mathrm{NaCl}, \mathrm{pH} 8.0$ ) with protease inhibitor $(1 \mathrm{mg} / \mathrm{ml}$ aprotinin, $1 \mathrm{mg} / \mathrm{ml}$ leupeptin, $1 \mathrm{mg} / \mathrm{ml}$ pepstatin A), and then centrifuged for 45 minutes at
65,000 rounds per minute (RPM) at 4 degrees Celsius. The supernatants were removed. The pellets were resuspended by sonication in a homogenization buffer containing $1 \%$ SDS, and spun again (15 minutes at 18,000 RPM). We collected the supernatants and measured the total protein amount of each sample. We obtained $110 \mu \mathrm{g}$ of protein from each harvested mouse brain sample or standard, and placed the sample into each well coated with a monoclonal antibody to the NH2-terminus of mouse $\mathrm{A} \beta$. The samples and the antibody were incubated overnight at 4 degrees Celsius. After washing 4 times, a rabbit monoclonal antibody specific for the $\mathrm{COOH}$-terminus of the $A \beta$ sequence (1-40 or 1-42) was added and incubated in room temperature for one hour. After another 4 washes, horseradish peroxidase-labeled anti-rabbit antibody was added to the wells, and incubated for a half hour at room temperature. Wells were then developed with tetramethylbenzidine (TMB) reagent in dark and the well absorbance was measured at $450 \mathrm{~nm}$. A $\beta 40$ and $A \beta 42$ levels in test samples were determined by comparison with the signals from the standard spiked with known quantities of $A \beta 40$ or $A \beta 42$.

\section{Western blot analysis}

BACE antibody (1:1,000 dilution; Abcam, Cambridge, MA, Cat. Number: ab2077) was used to recognize BACE $(65 \mathrm{kDa})$. Anti-neprilysin (NEP) antibody (1:1,000 dilution, Millipore, Temecula, CA) was used to detect protein levels of NEP (86 kDa). Antibody anti- $\beta$-Actin (1:10,000, Sigma, St. Louis, MO) was used to detect $\beta$-Actin (42 kDa). Each band in the Western blot represented an independent experiment. The results were averaged from 6-10 independent experiments. We quantified the Western blots in two steps as described in our previous studies [25]. First, we used $\beta$-Actin levels to normalize protein levels (e.g., determining the ratio of BACE to $\beta$-Actin amount) and control for loading differences in the total protein amount. Second, we presented protein level changes in the brain tissues of mice treated with propofol as a percentage of those in the saline control group. 100\% of protein level changes refer to control levels for the purpose of comparison to experimental conditions.

\section{Immunoblot detection of $A \beta$}

Immunoblot detection of $A \beta$ in brain tissues was measured as described in previous studies [25-27]. Specifically, brain samples were homogenized $(150 \mathrm{mM} \mathrm{NaCl}$ with protease inhibitor cocktail in $50 \mathrm{mM}$ Tris, $\mathrm{pH}$ of 8.0) and centrifuged $(65,000 \mathrm{rpm} \times 45$ minutes $)$, and the supernatant was removed. The pellet was then resuspended by sonication in homogenization buffer containing 1\% SDS. Following the pelleting of insoluble material $(18,000 \mathrm{rpm} \times$ 15 minutes), the SDS-extract was electrophoresed on SDS-PAGE (4-12\% Bis-Tris polyacrylamide gel from 
Invitrogen, Carlsbad, CA), blotted to PVDF membrane and probed with a 1:200 dilution of 6E10 (Covance).

\section{Statistics}

Data were expressed as mean \pm standard deviation (SD). The number of samples varied from 6 to 10, and the samples were normally distributed (tested by normality test). Student-t test was used to analyze the difference in $\mathrm{A} \beta, \mathrm{BACE}$, and NEP levels between the brain tissues of the propofol-treated mice and the brain tissues of the saline-treated mice. Prism 6 software (La Jolla, CA) was used to analyze the data.

\section{Results}

\section{Propofol treatment reduced the $A \beta$ levels in the brain tissues of aged mice}

Our recent studies [28] showed that chronic treatment with anesthetic propofol $(50 \mathrm{mg} / \mathrm{kg}$, once a week for 8 weeks) was able to improve cognitive function and attenuated the aging-associated caspase- 3 activation. Both caspase- 3 activation and $A \beta$ have been reported to contribute to $\mathrm{AD}$ neuropathogenesis and cognitive impairment ([29], reviewed in [1]). Therefore, we set out to determine whether the chronic propofol treatment could also reduce the $A \beta$ levels in the brain tissues of mice.

The 18 month-old mice received $50 \mathrm{mg} / \mathrm{kg}$ propofol or saline once a week for 8 weeks. On the day after the last propofol treatment, the mice were euthanized and the brain tissues were harvested. The harvested brain tissues were subjected to ELISA studies for the determination of $A \beta 40$ and $A \beta 42$ levels. The ELISA studies showed that the brain tissues from the propofol-treated mice had lower levels of $A \beta 40$ as compared to the brain tissues from the saline-treated mice: 42 versus $78 \mathrm{pg} /$ $1 \mathrm{mg}$ protein, $\mathrm{P}=0.027$ (Figure 1A). The ELISA studies also showed that the propofol treatment reduced the A 342 levels in the brain tissues of mice: 0.54 versus $0.89 \mathrm{pg} / 1 \mathrm{mg}$ protein, $\mathrm{P}=0.030$ (Figure 1B). These data suggested that the chronic treatment with propofol might decrease both $A \beta 40$ and $A \beta 42$ levels in brain tissues of aged mice.

Next, we performed Western blot analysis of $A \beta$ to further determine the effects of the propofol treatment on the $A \beta$ levels in the brain tissues of the aged mice. The immunoblotting of $A \beta$ showed that there was a visible reduction in the levels of bands representing $\mathrm{A} \beta(4 \mathrm{kDa})$ in the brain tissues of mice following the propofol treatment as compared to those of mice following the saline treatment (Figure 1C). There was no significant difference in the $\beta$-Actin levels between the brain tissues of mice following the propofol treatment and the brain tissues of mice following the saline treatment. The quantification of the Western blot, based on the ratio of $A \beta$ to $\beta$-Actin, showed that the propofol treatment (black bar) decreased the $A \beta$ levels as compared to the saline treatment (white bar): $43 \%$ versus $100 \%, P=0.001$ (Figure 1D). Taken together, these data suggested that the chronic treatment with $50 \mathrm{mg} / \mathrm{kg}$ propofol weekly for 8 weeks was able to decrease $A \beta$ levels in the brain tissues of aged mice.

\section{Propofol treatment reduced the BACE levels in the brain tissues of aged mice}

Given the findings that the propofol treatment could decrease the $A \beta$ levels in the brain tissues of aged mice, next, we investigated the potential underlying mechanisms. We used Western blot analysis to assess the effects of the propofol treatment on the level of BACE, the enzyme for the $A \beta$ generation [8]. The BACE immunoblotting showed that there were reduced levels in the levels of the bands representing BACE $(65 \mathrm{kDa})$ in the brain tissues of the propofol-treated mice (lanes 5 to 8 ) as compared to those of the saline-treated mice (lanes 1 to 4) (Figure 2A). The quantification of the Western blot showed that the propofol treatment (black bar) decreased the BACE levels as compared to saline treatment (white bar): $58 \%$ versus $100 \%, P=0.001$ (Figure $2 \mathrm{~B}$ ). These results suggested that the propofol treatment might decrease $A \beta$ levels by reducing its generation through inhibition of its generation enzyme, BACE.

\section{Propofol treatment increased the NEP levels in the brain tissues of aged mice}

The reduction of $A \beta$ could be due to either a decrease in its generation (e.g., decrease in BACE levels) or increase in its degradation. Neprilysin (NEP) is one of the enzymes of $A \beta$ degradation ([15-19]; reviewed in [20]). We therefore assessed the effects of the chronic propofol treatment on the levels of NEP in the brain tissues of the aged mice by employing the Western blot analysis. The NEP immunoblotting showed visible increases in the levels of bands representing NEP $(86 \mathrm{kDa})$ in the mice treated with propofol (lanes 4 to 6 ) as compared to those treated with saline (lanes 1 to 3 ) (Figure 3A). The quantification of the Western blot showed that the propofol treatment (black bar) increased the levels of NEP as compared to the saline treatment (white bar) in the brain tissues of the aged mice: $167 \%$ versus $100 \%, P=0.001$ (Figure 3B). These data suggested that the propofol treatment might also decrease $A \beta$ levels by increasing its degradation through promotion of its degradation enzyme, NEP.

\section{Discussion}

Our recent studies have shown that a weekly treatment with $50 \mathrm{mg} / \mathrm{kg}$ propofol for 8 weeks is able to improve the cognitive function in the aged mice, and reduces caspase-3 activation in the brain tissues of the mice [22]. $\mathrm{A} \beta$ accumulation also contributes to cognitive impairment [reviewed in [1]). Therefore, in the current study, we 

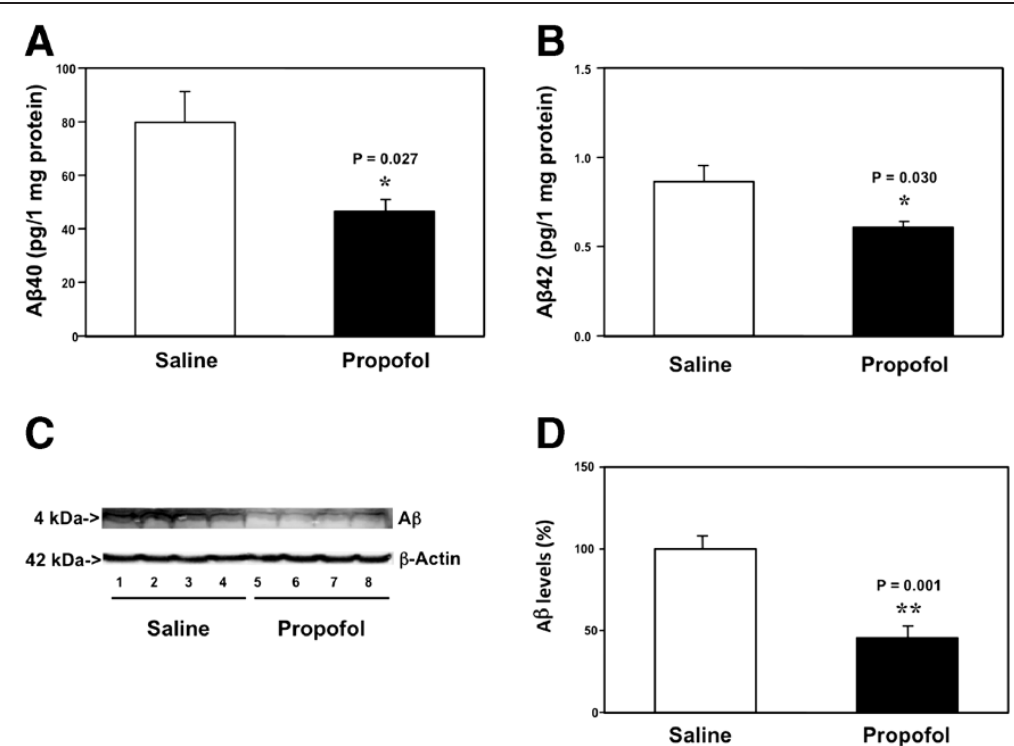

Figure 1 Propofol decreases $\mathbf{A} \boldsymbol{\beta}$ levels in the brain tissues of aged mice. A. ELISA shows that there are lower levels of $A \beta 40$ in the brain tissues of mice following the propofol treatment (black bar) as compared to the mice following the saline treatment (white bar). B. ELISA shows that there are lower levels of $A \beta 42$ in the brain tissues of mice following the propofol treatment (black bar) as compared to the mice following saline treatment (white bar). C. Western blot analysis shows that there are lower levels of A $\beta$ in the brain tissues of mice following propofol treatment (lanes 5 to 8) as compared to the mice following saline treatment (lanes 1 to 4 ). D. Quantification of the Western blot shows that there are lower levels of $A \beta$ in the brain tissues of mice following propofol treatment (black bar) as compared to the mice following saline treatment (white bar). $N=10$.

assessed the effects of the chronic treatment of propofol on the levels of $A \beta$, as well as its generation enzyme BACE and degradation enzyme NEP. Note that the main objective in this proof of concept study is to establish a pre-clinical model for future large scale studies.

We found that the weekly treatment of propofol for 8 weeks in the aged mice was able to attenuate the $A \beta$ levels in the brain tissues of the mice (Figure 1). These data suggested that it was possible that the anesthetic propofol might improve cognitive function in aged mice by reducing the $A \beta$ levels in the brain tissues of the mice. However, the cause-effect relationship of the propofolinduced reduction in brain $A \beta$ levels of aged mice and the propofol-induced improvement of cognitive function in aged mice remain to be determined. Such studies would illustrate the functional outcomes of the propofol-induced reduction in brain $A \beta$ levels of aged mice and are warranted to perform in the future.

Moreover, the propofol treatment decreased BACE levels in the brain tissues of the aged mice (Figure 2). These results showed the potential underlying mechanism of the propofol-induced reduction in $A \beta$ levels, and suggested that propofol might decrease the $A \beta$ levels by inhibiting its generation in the brain tissues of the mice.

Finally, the propofol treatment increased the NEP levels in the brain tissues of the aged mice (Figure 3). These findings demonstrated a different underlying mechanism of the propofol-induced reduction in $A \beta$ levels, and
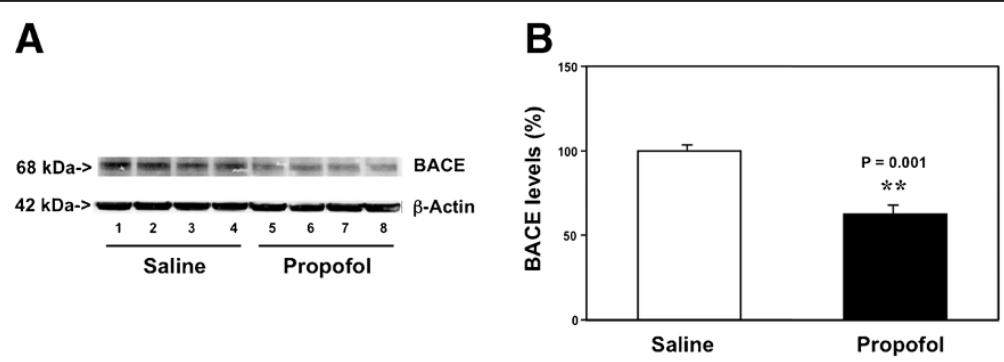

Figure 2 Propofol decreases BACE levels in the brain tissues of aged mice. A. Western blot analysis shows that there are lower levels of BACE in the brain tissues of mice following propofol treatment (lanes 5 to 8 ) as compared to the mice following saline treatment (lanes 1 to 4 ). B. Quantification of the Western blot shows that there are lower levels of BACE in the brain tissues of mice following propofol treatment (black bar) as compared to the mice following saline treatment (white bar). $N=6$. 


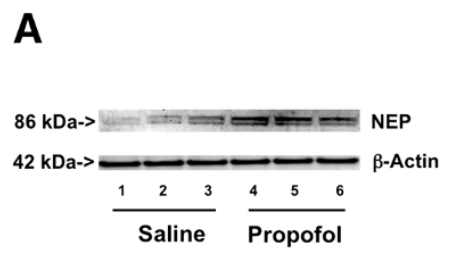

B

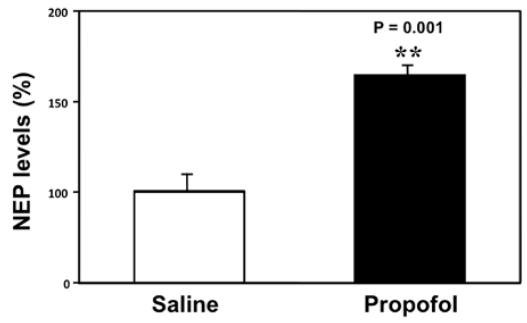

Figure 3 Propofol increases NEP levels in the brain tissues of aged mice. A. Western blot analysis shows that there are higher levels of NEP in the brain tissues of mice following propofol treatment (lanes 4 to 6) as compared to the mice following saline treatment (lanes 1 to 3 ). B. Quantification of the Western blot shows that there are higher levels of NEP in the brain tissues of mice following propofol treatment (black bar) as compared to the mice following saline treatment (white bar). $\mathrm{N}=6$.

suggested that propofol might decrease the $A \beta$ levels by enhancing its degradation in the brain tissues of the mice.

A recent study has shown that AD patients may have an age-dependent decrease of gamma-aminobutyric acid (GABA) currents in the AD brain, and this reduction is associated with decreased mRNA and protein levels of GABA receptor subunits [30]. These findings suggest that reduced GABA neurotransmission could also contribute to AD neuropathogenesis. Propofol is a GABA receptor agonist [31], and it has been shown in a preliminary clinical study that propofol may improve cognitive function in humans [32]. Our current studies showed that the chronic propofol treatment might decrease BACE levels (the generation enzyme) and increase NEP levels (the degradation enzyme), leading to reduction in $A \beta$ levels in brain tissues of aged mice. Furthermore, our recently published work [22] suggested that the same chronic propofol treatment was able to attenuate caspase- 3 activation in the brain tissues of aged mice and improved cognitive function in the mice. Taken together, these findings suggest the potential association between GABA neurotransmission with caspase activation, $A \beta$ metabolism and cognitive function. Future studies may use different GABA receptor agonist(s) to further test this hypothesis. These findings may promote more research, leading to new concepts of $\mathrm{AD}$ neuropathogenesis and new intervention (s) of AD.

Moreover, these findings demonstrated the possibility that the anesthetic propofol could be used to prevent or treat neurological disorders, e.g., AD. Pending further studies, the chronic treatment with propofol would be used to attenuate the neuropathogenesis of $\mathrm{AD}$ and to improve the cognitive function in $\mathrm{AD}$ patients. These studies would promote further investigations, in both pre-clinical and clinical settings, to seek innovative uses of current anesthetics for the interventions of other disorders.

Some anesthetics, e.g., isoflurane, have been shown to induce neurotoxicity and neurobehavioral deficits in vitro and in vivo [25,33-46]. Therefore, the current findings that propofol attenuated $A \beta$ levels in brain tissues of mice suggested that more studies are needed to assess whether propofol could be a better choice when providing anesthesia care for $\mathrm{AD}$ patients or senior patients who are vulnerable to develop postoperative cognitive dysfunction.

Note that propofol is a short acting anesthetic agent. The observed reductions in the levels of $A \beta$ and BACE, and increases in the NEP levels were likely not the acute effects of propofol. The exactly mechanism by which the chronic treatment of propofol alters the levels of $A \beta$, BACE, and NEP remains unknown at the current time. We have postulated that the weekly treatment with $50 \mathrm{mg} / \mathrm{kg}$ propofol for 8 weeks may regulate the functional status of GABA receptor, which then leads to the changes in the levels of $A \beta, B A C E$, and NEP. Future studies to test this hypothesis are warranted.

The studies have several limitations. First, we did not determine the dose or time-dependent effects of propofol on $A \beta$ levels in the brain tissues of the aged mice. Different treatments of propofol may be neurotoxic [47-49] or neuroprotective [50-52]. Therefore, it is possible that propofol treatment with different doses or administered at different times may have different effects on brain $A \beta$ levels. Nevertheless, the outcomes from the current studies have established a system and proposed a new concept to further determine the effects of propofol on brain function. Second, we did not assess the effects of propofol on the levels of other enzymes involving in $A \beta$ metabolism, e.g., $\gamma$-secretase and/or insulin degradation enzyme (IDE). However, the main objective of the current studies was to determine whether anesthetic propofol could decrease brain $A \beta$ levels in aged mice. We will systematically investigate the underlying mechanism by which propofol affects brain $A \beta$ levels using our established system in the future.

In conclusion, we found that chronic treatment with the anesthetic propofol was able to reduce $A \beta$ (both $A \beta 40$ and $A \beta 42$ ) levels in the brain tissues of aged mice. Furthermore, the chronic propofol treatment might reduce the brain $A \beta$ levels by decreasing brain $B A C E$ levels (decreasing $A \beta$ generation) and increasing brain 
NEP levels (increasing A $\beta$ degradation). The findings from these concept and hypothesis generation studies will promote more research to systematically determine the effect of chronic treatment of propofol or other anesthetics on $A \beta$ levels and the associated behavioral changes, which would ultimately lead to the development of new therapeutic strategies for aging- and/or AD-associated cognitive impairment and of better anesthesia care for senior and $\mathrm{AD}$ patients.

\section{Abbreviations}

AD: Alzheimer's disease; APP: Amyloid $\beta$ precursor protein; BACE: $\beta$-site amyloid precursor protein cleaving enzyme; NEP: Neprilysin.

\section{Competing interests}

The authors have no conflicts of interest for the study.

\section{Authors' contributions}

$Y Z$ and $Z X$ designed the experiments; $Y Z, H S$ and $Y D$ carried our the experiments; $Y Z, C S$ and BY analyzed the data; $W X$ and $Z X$ wrote the paper. All authors read and approved the final manuscript.

\section{Acknowledgement}

This research was supported by R21AG038994, R01 GM088801 and R01 AG041274 from National Institutes of Health, Bethesda, Maryland, Investigator-initiated Research grant from Alzheimer's Association, Chicago, Illinois, and Cure Alzheimer's Fund, Wellesley, Massachusetts to Zhongcong Xie. The cost of the anesthetic propofol was generously provided by the Department of Anesthesia, Critical Care and Pain Medicine at Massachusetts General Hospital and Harvard Medical School, Boston, Massachusetts.

\section{Author details}

${ }^{1}$ Geriatric Anesthesia Research Unit, Department of Anesthesia, Critical Care and Pain Medicine, Massachusetts General Hospital and Harvard Medical School, 149 13th St., Room 4310, Charlestown, MA 02129-2060, USA. ${ }^{2}$ Department of Anesthesiology, Ruijin Hospital, Shanghai Jiao Tong University School of Medicine, 200025 Shanghai, P.R. China. ${ }^{3}$ Department of Veterans Affairs, Medical Research and Development Service and Geriatric Research, Education and Clinical Center, Bedford, MA 01730, UK.

\section{Received: 3 February 2014 Accepted: 1 April 2014}

Published: 11 April 2014

\section{References}

1. Querfurth HW, LaFerla FM: Alzheimer's disease. N Engl J Med 2010, 362(4):329-344

2. Goate A, Chartier-Harlin MC, Mullan M, Brown J, Crawford F, Fidani L, Giuffra L, Haynes A, Irving N, James L, Mant R, Newton P, Rooke K, Roques P, Talbot C, Pericak-Vance M, Roses A, Williamson R, Rossor M, Owen M, Hardy J: Segregation of a missense mutation in the amyloid precursor protein gene with familial Alzheimer's disease. Nature 1991, 349(6311):704-706.

3. Masters CL, Simms G, Weinman NA, Multhaup G, McDonald BL, Beyreuther K: Amyloid plaque core protein in Alzheimer disease and Down syndrome. Proc Natl Acad Sci U S A 1985, 82(12):4245-4249.

4. Selkoe DJ, Podlisny MB, Joachim CL, Selkoe DJ, Podlisny MB, Joachim CL, Selkoe DJ, Podlisny MB, Joachim CL, Vickers EA, Lee G, Fritz LC, Oltersdorf T: Beta-amyloid precursor protein of Alzheimer disease occurs as 110- to 135-kilodalton membrane-associated proteins in neural and nonneural tissues. Proc Natl Acad Sci U S A 1988, 85(19):7341-7345.

5. Glenner GG, Wong CW: Alzheimer's disease and Down's syndrome: sharing of a unique cerebrovascular amyloid fibril protein. Biochem Biophys Res Commun 1984, 122(3):1131-1135.

6. Tanzi RE, Gusella JF, Watkins PC, Bruns GA, St George-Hyslop P, Van Keuren ML, Patterson D, Pagan S, Kurnit DM, Neve RL: Amyloid beta protein gene: CDNA, mRNA distribution, and genetic linkage near the Alzheimer locus. Science 1987, 235(4791):880-884.

7. Kang J, Lemaire HG, Unterbeck A, Salbaum JM, Masters CL, Grzeschik KH, Multhaup G, Beyreuther K, Müller-Hill B: The precursor of Alzheimer's disease amyloid A4 protein resembles a cell-surface receptor. Nature 1987, 325(6106):19-25. 733-6.

8. Vassar R, Bennett BD, Babu-Khan S, Kahn S, Mendiaz EA, Denis P, Teplow DB, Ross S, Amarante P, Loeloff R, Luo Y, Fisher S, Fuller J, Edenson S, Lile J, Jarosinski MA, Biere AL, Curran E, Burgess T, Louis JC, Collins F, Treanor J, Rogers G, Citron M: Beta-secretase cleavage of Alzheimer's amyloid precursor protein by the transmembrane aspartic protease BACE. Science 1999, 286(5440):735-741.

9. Hussain I, Powell D, Howlett DR, Tew DG, Meek TD, Chapman C, Gloger IS, Murphy KE, Southan CD, Ryan DM, Smith TS, Simmons DL, Walsh FS, Dingwall C, Christie G: Identification of a novel aspartic protease (Asp 2) as beta-secretase. Mol Cell Neurosci 1999, 14(6):419-427.

10. Sinha S, Lieberburg I: Cellular mechanisms of beta-amyloid production and secretion. Proc Natl Acad Sci U S A 1999, 96(20):11049-11053.

11. Yan R, Bienkowski MJ, Shuck ME, Miao H, Tory MC, Pauley AM, Brashier JR, Stratman NC, Mathews WR, Buhl AE, Carter DB, Tomasselli AG, Parodi LA, Heinrikson RL, Gurney ME: Membrane-anchored aspartyl protease with Alzheimer's disease beta-secretase activity. Nature 1999, 402(6761):533-537.

12. Gu Y, Misonou H, Sato T, Dohmae N, Takio K, Ihara Y: Distinct intramembrane cleavage of the beta-amyloid precursor protein family resembling gamma-secretase-like cleavage of Notch. J Biol Chem 2001, 276(38):35235-35238.

13. Sastre M, Steiner H, Fuchs K, Capell A, Multhaup G, Condron MM, Teplow DB, Haass C: Presenilin-dependent gamma-secretase processing of beta-amyloid precursor protein at a site corresponding to the S3 cleavage of Notch. EMBO Rep 2001, 2(9):835-841.

14. Yu C, Kim SH, Ikeuchi T, Xu H, Gasparini L, Wang R, Sisodia SS: Characterization of a presenilin-mediated amyloid precursor protein carboxyl-terminal fragment gamma. Evidence for distinct mechanisms involved in gamma -secretase processing of the APP and Notch1 transmembrane domains. J Biol Chem 2001, 276(47):43756-43760.

15. Eckman EA, Eckman CB: Abeta-degrading enzymes: modulators of Alzheimer's disease pathogenesis and targets for therapeutic intervention. Biochem Soc Trans 2005, 33(Pt 5):1101-1105.

16. Higuchi M, Iwata N, Saido TC: Understanding molecular mechanisms of proteolysis in Alzheimer's disease: progress toward therapeutic interventions. Biochim Biophys Acta 2005, 1751(1):60-67.

17. Wang DS, Dickson DW, Malter JS: beta-Amyloid degradation and Alzheimer's disease. J Biomed Biotechnol 2006, 2006(3):58406.

18. Miners JS, Baig S, Palmer J, Palmer LE, Kehoe PG, Love S: Abeta-degrading enzymes in Alzheimer's disease. Brain Pathol 2008, 18(2):240-252.

19. Bates KA, Verdile G, Li OX, Ames D, Hudson P, Masters CL, Martins RN: Clearance mechanisms of Alzheimer's amyloid-beta peptide: implications for therapeutic design and diagnostic tests. Mol Psychiatry 2009, 14(5):469-486.

20. Qiu WQ, Folstein MF: Insulin, insulin-degrading enzyme and amyloid-beta peptide in Alzheimer's disease: review and hypothesis. Neurobiol Aging 2006, 27(2):190-198

21. Zhang Y, Zhen Y, Dong Y, Xu Z, Yue Y, Golde TE, Tanzi RE, Moir RD, Xie Z: Anesthetic propofol attenuates the isoflurane-induced caspase-3 activation and abeta oligomerization. PLoS One 2011, 6(11):e27019.

22. Shao H, Zhang Y, Dong Y, Yu B, Xia W, Xie Z: Chronic treatment with anesthetic propofol improves cognitive function and attenuates caspase activation in both aged and Alzheimer's disease transgenic mice. J Alzheimers Dis 2014. In Press.

23. Zhang Y, Dong Y, Wu X, Lu Y, Xu Z, Knapp A, Yue Y, Xu T, Xie Z: The mitochondrial pathway of anesthetic isoflurane-induced apoptosis. $J$ Biol Chem 2010, 285(6):4025-4037.

24. Xu Z, Dong Y, Wang H, Culley DJ, Marcantonio ER, Crosby G, Tanzi RE, Zhang $Y$, Xie $Z$ : Age-dependent postoperative cognitive impairment and Alzheimer-related neuropathology in mice. Sci Rep 2014, 4:3766.

25. Xie Z, Culley DJ, Dong Y, Zhang G, Zhang B, Moir RD, Frosch MP, Crosby G, Tanzi RE: The common inhalation anesthetic isoflurane induces caspase activation and increases amyloid beta-protein level in vivo. Ann Neurol 2008, 64(6):618-627.

26. Nagano S, Huang X, Moir RD, Payton SM, Tanzi RE, Bush Al: Peroxidase activity of cyclooxygenase-2 (COX-2) cross-links beta-amyloid (Abeta) and generates Abeta-COX-2 hetero-oligomers that are increased in Alzheimer's disease. J Biol Chem 2004, 279(15):14673-14678.

27. Dong Y, Zhang G, Zhang B, Moir RD, Xia W, Marcantonio ER, Culley DJ, Crosby G, Tanzi RE, Xie Z: The common inhalational anesthetic 
sevoflurane induces apoptosis and increases beta-amyloid protein levels. Arch Neurol 2009, 66(5):620-631.

28. Haijun Shao YZ, Yuanlin D, Buwei Y, Weiming Xia Zhongcong X: Chronic treatment with anesthetic propofol improves cognitive function and attenuates caspase activation in both aged and Alzheimer's disease transgenic mice. J Alzheimers Dis. In Press.

29. Burguillos MA, Deierborg T, Kavanagh E, Persson A, Hajji N, Garcia-Quintanilla A, Cano J, Brundin P, Englund E, Venero JL, Joseph B: Caspase signalling controls microglia activation and neurotoxicity. Nature 2011, 472(7343):319-324.

30. Limon A, Reyes-Ruiz JM, Miledi R: Loss of functional GABA(A) receptors in the Alzheimer diseased brain. Proc Natl Acad Sci U S A 2012, 109(25):10071-10076.

31. Hales TG, Lambert JJ: The actions of propofol on inhibitory amino acid receptors of bovine adrenomedullary chromaffin cells and rodent central neurones. Br J Pharmacol 1991, 104(3):619-628.

32. Pryor $K$, Blackstock Bernstein AS, Feiler D, Vortsman E, Root JC: Administration of Propofol After Learning Improves Memory Performance in Human Subjects Via Loss of Competitive Consolidation: Evidence That Propofol Amnesia Occurs at the Induction of Consolidation. Anesthesiol 2012. ASA Abstract.

33. Eckenhoff RG, Johansson JS, Wei H, Carnini A, Kang B, Wei W, Pidikiti R Keller JM, Eckenhoff MF: Inhaled anesthetic enhancement of amyloid-beta oligomerization and cytotoxicity. Anesthesiol 2004, 101(3):703-709.

34. Brambrink AM, Evers AS, Avidan MS, Farber NB, Smith DJ, Zhang X, Dissen GA, Creeley CE, Olney JW: Isoflurane-induced neuroapoptosis in the neonatal rhesus macaque brain. Anesthesiology 2010, 112(4):834-841.

35. Xie Z, Dong Y, Maeda U, Alfille P, Culley DJ, Crosby G, Tanzi RE: The common inhalation anesthetic isoflurane induces apoptosis and increases amyloid beta protein levels. Anesthesiol 2006, 104(5):988-994.

36. Xie Z, Dong Y, Maeda U, Moir R, Inouye SK, Culley DJ, Crosby G, Tanzi RE: Isoflurane-induced apoptosis: a potential pathogenic link between delirium and dementia. J Gerontol A Biol Sci Med Sci 2006, 61(12):1300-1306.

37. Wei H, Kang B, Wei W, Liang G, Meng QC, Li Y, Eckenhoff RG: Isoflurane and sevoflurane affect cell survival and BCL-2/BAX ratio differently. Brain Res 2005, 1037(1-2):139-147.

38. Loop T, Dovi-Akue D, Frick M, Roesslein M, Egger L, Humar M, Hoetzel A, Schmidt R, Borner C, Pahl HL, Geiger KK, Pannen BH: Volatile anesthetics induce caspase-dependent, mitochondria-mediated apoptosis in human T lymphocytes in vitro. Anesthesiol 2005, 102(6):1147-1157.

39. Wei H, Liang G, Yang H, Wang Q, Hawkins B, Madesh M, Wang S, Eckenhoff RG: The common inhalational anesthetic isoflurane induces apoptosis via activation of inositol 1,4,5-trisphosphate receptors. Anesthesiol 2008, 108(2):251-260.

40. Xie Z, Dong Y, Maeda U, Moir RD, Xia W, Culley DJ, Crosby G, Tanzi RE: The inhalation anesthetic isoflurane induces a vicious cycle of apoptosis and amyloid beta-protein accumulation. J Neurosci 2007, 27(6):1247-1254.

41. Shu Y, Zhou Z, Wan Y, Sanders RD, Li M, Pac-Soo CK, Maze M, Ma D: Nociceptive stimuli enhance anesthetic-induced neuroapoptosis in the rat developing brain. Neurobiol Dis 2012, 45(2):743-750.

42. Zhao X, Yang Z, Liang G, Wu Z, Peng Y, Joseph DJ, Inan S, Wei H: Dual Effects of Isoflurane on Proliferation, Differentiation, and Survival in Human Neuroprogenitor Cells. Anesthesiol 2013, 118(3):537-549.

43. Sanders RD, Hassell J, Davidson AJ, Robertson NJ, Ma D: Impact of anaesthetics and surgery on neurodevelopment: an update. British $J$ Anaesthesia 2013, 110(Suppl 1):i53-72.

44. Jevtovic-Todorovic V, Absalom AR, Blomgren K, Brambrink A, Crosby G, Culley DJ, Fiskum G, Giffard RG, Herold KF, Loepke AW, Ma D, Orser BA Planel E, Slikker W Jr, Soriano SG, Stratmann G, Vutskits L, Xie Z, Hemmings HC Jr: Anaesthetic neurotoxicity and neuroplasticity: an expert group report and statement based on the BJA Salzburg Seminar. British J Anaesthesia 2013, 111(2):143-151.

45. Zhang B, Tian M, Zhen Y, Yue Y, Sherman J, Zheng H, Li S, Tanzi RE, Marcantonio ER, Xie Z: The effects of isoflurane and desflurane on cognitive function in humans. Anesth Analg 2012, 114(2):410-415.

46. Zhang Y, Xu Z, Wang H, Dong Y, Shi HN, Culley DJ, Crosby G, Marcantonio ER, Tanzi RE, Xie Z: Anesthetics isoflurane and desflurane differently affect mitochondrial function, learning, and memory. Ann Neurol 2012, 71(5):687-698.

47. Pearn ML, Hu Y, Niesman IR, Patel HH, Drummond JC, Roth DM, Akassoglou K, Patel PM, Head BP: Propofol neurotoxicity is mediated by p75 neurotrophin receptor activation. Anesthesiol 2012, 116(2):352-361.
48. Whittington RA, Virag L, Marcouiller F, Papon MA, El Khoury NB, Julien C, Morin F, Emala CW, Planel E: Propofol directly increases tau phosphorylation. PLoS One 2011, 6(1):e16648.

49. Krzisch M, Sultan S, Sandell J, Demeter K, Vutskits L, Toni N: Propofol Anesthesia Impairs the Maturation and Survival of Adult-born Hippocampal Neurons. Anesthesiology 2013, 118(3):602-610.

50. Bayona NA, Gelb AW, Jiang Z, Wilson JX, Urquhart BL, Cechetto DF: Propofol neuroprotection in cerebral ischemia and its effects on low-molecular-weight antioxidants and skilled motor tasks. Anesthesiol 2004, 100(5):1151-1159.

51. Zhang $Y$, Dong $Y, X u Z$, Xie Z: Propofol and magnesium attenuate isofluraneinduced caspase- 3 activation via inhibiting mitochondrial permeability transition pore. Med Gas Res 2012, 2(1):20.

52. Rossaint J, Rossaint R, Weis J, Fries M, Rex S, Coburn M: Propofol: neuroprotection in an in vitro model of traumatic brain injury. Crit Care 2009, 13(2):R61.

doi:10.1186/2047-9158-3-8

Cite this article as: Zhang et al:: Chronic treatment with anesthetic propofol attenuates $\beta$-amyloid protein levels in brain tissues of aged mice. Translational Neurodegeneration 2014 3:8.

\section{Submit your next manuscript to BioMed Central and take full advantage of:}

- Convenient online submission

- Thorough peer review

- No space constraints or color figure charges

- Immediate publication on acceptance

- Inclusion in PubMed, CAS, Scopus and Google Scholar

- Research which is freely available for redistribution

Submit your manuscript at www.biomedcentral.com/submit
C Biomed Central 